\title{
APPLICATION OF BIOREACTOR LANDFILL TECHNOLOGY TO MUNICIPAL SOLID WASTE MANAGEMENT: ASIAN PERSPECTIVE
}

\author{
Chart Chiemchaisri ${ }^{1}$ \\ Kurian Joseph ${ }^{2}$ \\ ${ }^{\prime}$ Kasetsart University, Thailand \\ ${ }^{2}$ Anna University, India
}

\begin{abstract}
In recent years, due to the advance in knowledge of landfill behaviour and decomposition processes of municipal solid waste (MSW), there has been a strong thrust to upgrade existing landfill technology from a storage/containment concept to a process-based approach, in other words, as a bioreactor landfill. Operating landfills as bioreactors and hence enhancing the stabilization of wastes is one such option that has been elaborately investigated and had already been in practice in the U.S. and European countries. As compared to many developed countries, the concept of leachate recirculation is still relatively new to Asia. Nevertheless, there are laboratory scale and pilot scale researches including few full-scale implementation of this technology in Asia. Research and development activities relating to aspects of landfill bioreactors are keeping the interest of scientists and engineers alive and enriching the literatures. Findings of bioreactor landfill research have resulted in generation of enormous data and their publication in variety of journals and books. Collating data from such diverse sources would help understand the bioreactor landfill concept, benefits to be derived, design and operational issues, possible solutions to many of these issues, ongoing researches, etc. This paper is an attempt to present an overview in this direction in Asian perspective.
\end{abstract}

\section{KEYWORDS}

Bioreactor landfill; Developing countries; Solid waste disposal; Tropical climate.

\section{INTRODUCTION}

The modern sanitary landfill is an important component of today's integrated solid waste management system. However, in order to advance the field of solid waste management, new and innovative ways of managing solid waste disposal need to be continually evaluated. One idea that has gained significant attention in the last several years is the "bioreactor landfill". This paper is intended to raise reader awareness that the bioreactor landfill is an emerging viable option for solid waste management. It is hoped that landfill owners and operators, policy makers, regulators, others concerned with the environment, and the public at large will use this paper as a focal point for future discussion. Municipal solid wastes from developing countries are mainly composed of easily biodegradable organic matter with high moisture content especially in tropical climate. Therefore, providing different environmental conditions for microbial activities in the Bioreactor landfill should be taken into consideration. 


\section{SOLID WASTE DISPOSAL BY LANDFILL}

In the 1920s and 1930s, sanitary landfills were first constructed to replace the open dumps that posed, and some continue to pose, significant threats to human and environmental health. These primitive landfills were, literally, naturally occurring depressions in the landscape that were filled with waste and then covered with a minimum amount of soil. Sand and gravel pits and borrow areas were also commonly filled to form primitive landfills. Modern landfills, in contrast, are highly engineered containment systems, designed to minimize the impact of municipal solid waste (MSW) on the environment and human health.

In modern sanitary landfills, the waste is isolated from the ground water by a liner system, and rain water is prevented from entering the waste by a landfill cap. This method of $d r y$ tomb landfilling minimizes the potential environmental impact of the leachate by reducing the generation of leachate and containing the leachate within the landfill. Leachate is water that has moved through the landfill and collected water-soluble compounds from the waste. If leachate migrates from the landfill and contaminates the surrounding soil and ground water, it can pose a risk to human and environmental health.

This dry-tomb method of landfilling is primarily a storage method for solid waste. The storage of solid waste in this manner requires land-use restrictions and continuing maintenance. In the absence of perpetual maintenance, landfill caps may fail, allowing the infiltration of rain water and the subsequent uncontrolled generation of leachate. If the liner system also fails, this leachate could pose serious health risks to the community and the environment [1].

In Asian region typical design of sanitary landfill in lowland or floodplain area is shallow landfill with only 3-4 lifts (6-8 m. depth) covering large land area in order to prevent severe contamination to subsurface water. Therefore, huge amount of leachate being generated during rainy or especially monsoon season provides environmental threats and difficulties in their management [2]. When consider about seasonal variations in Asia, leachate generation of landfills in South and Southeast Asia are influenced by a distinct dry season of up to 150 days a year, a wet season with intensive rainfall events within a few hours, high temperatures and high solar radiation $[2,3]$.

In South and Southeast Asia, more than $90 \%$ of all landfills are non-engineered disposal facilities and this indiscriminate dumping leads to heaps of uncovered waste, open burning, pools of standing polluted water, insects and rodent infestations and families of waste scavengers picking up any valuables [4]. It is essential to have environmentally sound management of MSW for public health, well being, and sustainability of the urban environment [5]. Reclamation and rehabilitation of dumpsites have been suggested as a strategic approach for sustainable waste disposal [6,7]. According to Visvanathan [8], sustainable landfill management in Asia can be achieved in the long term, by moving from open dumping to advanced standards of sanitary landfill in a phase manner.

Leachate recirculation into MSW to operate a landfill as a bioreactor is a potential component of biofactory approach for treatment of organically rich MSW [9]. The ability of leachate recirculation to enhance the biodegradation and the leaching of the easily leachable components has been widely investigated [8-18]. Additionally, recirculation promotes the 
stabilization of the landfilled waste through the provision of optimum moisture conditions, a more effective transfer of microbes, substrates, and nutrients throughout the waste body and dilution of high concentrations of inhibiting substances proving to be potential.

\section{CONSIDERATIONS OF BIOREACTOR LANDFILL APPLICATION IN ASIA}

The open dump approach is the primitive waste disposal option in most of the developing countries owing to their low initial costs and lack of experience and equipment [19]. Since many developing countries belong to Asia, it is obvious that this open dump approach is their only sole option for final waste disposal. But the main problem of this approach is they pose significant risks to human health and the environment, especially as MSW become more complex in industrializing countries. Contaminated ground water may never be returned to usable condition and other environmental impacts may take many decades to ameliorate. These unplanned heaps of uncovered wastes, often burning and surrounded by pools of stagnated polluted water, rat and fly infestations with domestic animals roaming freely and families of scavengers picking through the wastes is not only an eyesore but a great environmental hazard [20]. So, the bioreactor landfill concept can play a major role in giving solutions to all these problems. But when operating bioreactor concept in Asia, there should be some climatic considerations taken into account. For instance the experiments on bioreactor landfill were mostly conducted under semi-arid climatic condition using wastes with relatively low moisture content. In contrary, MSW from Asian region is mainly composed of easily biodegradable organic matter with high moisture content especially in tropical climate, therefore, providing different environmental conditions for microbial biodegradation.

Several considerations about bioreactor landfills must be examined and understood before the government can identify specific bioreactor standards or recommend operating parameters. Bioreactor landfills generally are engineered systems that have higher initial capital costs and require additional monitoring and control during their operating life, but are expected to involve less monitoring over the duration of the post-closure period than conventional "dry tomb" landfills. Issues that need to be addressed during both design and operation of a bioreactor landfill include:

- Increased gas emissions

- Increased odours

- Physical instability of waste mass due to increased moisture and density

- Instability of liner systems

- Surface seeps

- Landfill fires

Leachate recirculation also has few disadvantages. These disadvantages include (1) reduction in the shear strength of municipal solid waste, potentially reducing the factor of safety for slope stability of the landfill; (2) potential leachate breakouts from the sides of the landfill; and (3) increase in the liquid pressure head on the liner, potentially increasing the risk for ground water contamination [21,22]. Hence, designers and landfills owners are expected to weigh the advantages and disadvantages on a site-specific basis before a leachate recirculation system is implemented.

\section{SHORT REVIEWS ON BIOREACTOR LANDFILL STUDIES}


As early as the 1970s, researchers started exploring the potential of applying leachate recirculation in landfills to enhance the stabilization of waste and production of landfill gas.

This resulted in a significant amount of research conducted at laboratory and lysimeter-scale followed by full-scale trials over the past two decades [23].

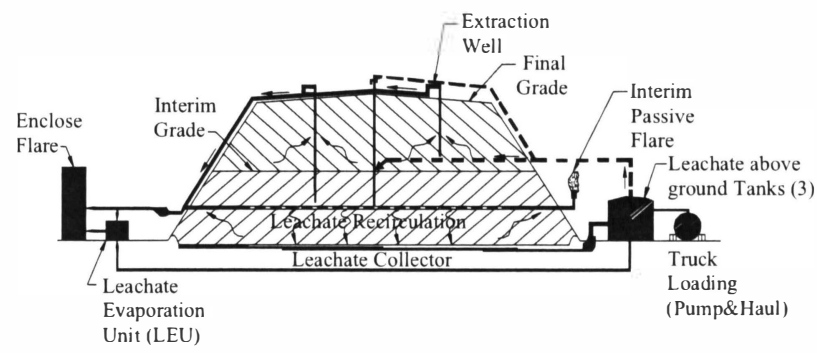

Figure 1. Leachate recirculation in bioreactor landfill.

\subsection{Laboratory and lysimeter demonstrations}

Early experiments had the objective of evaluating chemical characteristics of leachate and biogas from landfill to study landfill behaviour $[24,25]$. These studies measured the leachate production or water balance for assessing the volume of leachate sent to treatment units. Thus, sizes of bioreactors were quite large until 1975, when Pohland [26] conducted one of the first experiments on leachate recirculation. The experiment, supported by USEPA, showed the importance of leachate recirculation and $\mathrm{pH}$ control. After this, the sizes of bioreactor have been smaller, involved no complicated operation, and tested no other factor except the effects of leachate recirculation. For example, the smaller bioreactor with $400 \mathrm{~L}$ capacity was used to study the temperature effect to find optimum temperature to accelerate waste biodegradation. Since 1985, the experiment has changed its focus from energy recovery to co-disposal. Pohland et al [27] found that apart from accelerated stabilization of solid waste in laboratory scale by leachate recirculation, it was possible to work with hazardous waste co disposed with industrial waste sludge. The test results found that leachate recirculation could enhance complexation and precipitation of heavy metals while solid waste stabilization occurred. Recently, many researches were aimed at sequential operation with leachate recirculation in laboratory scale. The experiments used leachate recirculation from one unit that had already been stabilized to the other young units, as the results showed quick stabilization in young units [28]. A few examples of laboratory and pilot scale bioreactor studies in Asia are illustrated in Table 1.

A few important observations include short-circuiting that occurs during leachate recirculation, preventing achievement of field capacity for most of the landfill. Continuous pumping of leachate at two to three times the generation rate is necessary to avoid head build up on the liner. A more permeable intermediate cover may be more efficient in rapidly reaching field capacity than leachate recirculation. Low permeability, intermediate cover, and heterogeneity of the waste can lead to side seeping of leachate. Accelerated gas production 
may lead to odour if not accommodated by aggressive LFG collection. Leachate infiltration and collection piping are vulnerable to irregular settling and clogging. If waste is less permeable than anticipated, increased condensate production leads to short circuiting of moisture into landfill gas collection pipes. Storage must be provided to manage leachate during wet weather periods. Conversely, leachate may not be sufficient in volume to completely wet waste, particularly for aerobic bioreactors. Increased internal pore pressure due to high moisture content may lead to reduced factor of safety against slope stability and must be considered during the design process; and channeling leads to immediate leachate production, however long term recirculation increases uniform wetting and declining leachate generation as the waste moisture content approaches field capacity.

Table 1. Some examples of laboratory and pilot scale bioreactor studies in Asia.

\begin{tabular}{|c|c|c|c|}
\hline Research Title & Reference & Country & Conclusion \\
\hline $\begin{array}{l}\text { Application of leachate } \\
\text { storage and re-circulation } \\
\text { operating technique to } \\
\text { tropical landfill }\end{array}$ & $\begin{array}{c}\text { Chiemchaisri } \\
\text { et al [29] }\end{array}$ & Thailand & $\begin{array}{l}\text { Leachate re-circulation and storage } \\
\text { operation yielded lower organic } \\
\text { concentration in leachate whereas } \\
\text { methane content in landfill gas was } \\
\text { found highest. Leachate recirculation } \\
\text { enhanced degree of waste stabilization. }\end{array}$ \\
\hline $\begin{array}{l}\text { Effect of precipitation on } \\
\text { municipal solid waste } \\
\text { decomposition and methane } \\
\text { production in simulated } \\
\text { landfill bioreactor with } \\
\text { leachate recirculation }\end{array}$ & $\begin{array}{l}\text { Petchsri } \\
\text { et al. [3] }\end{array}$ & Thailand & $\begin{array}{l}\text { Leachate recirculation with } \\
\text { precipitation led to greater performance } \\
\text { in terms of accelerated biological } \\
\text { stabilization and the onset of } \\
\text { methanogenesis. }\end{array}$ \\
\hline
\end{tabular}

Leachate recirculation into the waste mass can be a potential option to treat

Bioreactor landfill lysimeter studies on Indian urban refuse

Swati et al.

Performance of bioreactor landfill with waste mined from a dumpsite.

Karthikeyan India
et al. [9]

India MSW leachate. Reduction in pollution indicators like organic contents BOD, COD and DOC, and solids was evident in leachate from bioreactor as compared to conventional open fill. Substantial decrease in organic matter and clear decrease in nutrient concentrations over a period of 1 year was observed in bioreactor landfill with leachate recirculation.

High removals of $\mathrm{COD}, \mathrm{BOD}_{5}, \mathrm{NH}_{4}^{+}$ and total nitrogen were achieved in the leachate recirculation reactors operated with aeration. Aeration strategy has positive impacts on the solid waste stabilization; addition of active sludge in reactor is favorable for the remediation of the nitrogen. 
Table 1. Some examples of laboratory and pilot scale bioreactor studies in Asia (cont.)

Performance of leachate nitrogen removal in bioreactor landfill system

Characteristics of the bioreactor landfill system using anaerobic-aerobic process for nitrogen removal

Pilot-scale experiment on anaerobic bioreactor landfills in China
He et al. [34] China

Jianguo et al. [35]

Intermittent aeration at the top of landfill refuse could stimulate the growth of nitrifying and denitrifying He et al [33] China bacteria. The bioreactor landfill system with intermittent aeration at the top of landfill refuse increased the potential of nitrogen removal from re-circulated leachate in the landfill bioreactor

Sequential anaerobic-aerobic process removes more than $90 \%$ of $\mathrm{COD}$ and almost $100 \%$ of $\mathrm{NH}_{4}{ }^{+}-\mathrm{N}$ from leachate under the optimum organic loading rate.

Leachate recirculation at high rate of $5.3 \%(\mathrm{v} / \mathrm{v})$ per week can be adopted as an effective in situ (pre)treatment approach to remove organic pollutants in leachate. It can accelerate solid waste degradation, landfill stabilization and landfill gas generation.

Effect of acidification percentage and volatile organic acids on the anaerobic biological process in simulated landfill bioreactors

Comparison between controlled landfill reactor and conditioned landfill bioreactor

Effect of leachate recycling and inoculation on the biochemical characteristics of municipal refuse in landfill bioreactors

Evaluation of in situ ammonia removal in an aerated landfill bioreactor
Wang et al. [36]

China

Anaerobic landfill bioreactor with leachate circulation in situ had two clear lag-phases while two-phase bioreactor had shorter lag phase.
An obvious enhancement of effective disposal from conservative sanitary landfill simulator to leachaterecirculated landfill simulator and to the Luo et al. China conditioned bioreactor landfill simulator [37] was noted through comparing solid waste settlement, heavy metal concentration in leachate, methane production rate, biogas composition and $\mathrm{BOD} / \mathrm{COD}$ ratio.

The enzymes (amylase, protease, cellulase, lipase and pectinase) for waste
Shen et al. China [38]

Mertoglu et al. [39]
Japan and Turkey degradation were present in fresh refuse but at low values and they were positively induced by leachate recycling and refuse inoculation.

Viability of rapid aerobic biostabilization in an aerated landfill bioreactor operated at various ORP levels was studied. Rapid BOD degradation in the aerated landfill bioreactor increased the possibility of nitrification by promoting nitrifying bacteria having high oxygen affinities. 


\subsection{Full-fledged bioreactor landfill facilities in Asia}

Following the positive results demonstrated by small-scale and pilot-scale studies, there has been an increase in the number of cases reported in recent years on the practice of leachate recirculation in full-scale operating landfills in countries such as the U.K., Germany and U.S.A. However, the research and development devoted to full-scale investigations are still relatively limited, due mainly to a poor regulatory awareness and negative perception. Landfill regulations in many countries still do not encourage the practice of leachate recirculation because of the concern that feeding back the highly polluted leachate into a landfill may concentrate the pollutants and overload the containment system. Also as compared to many developed countries, the concept of leachate recirculation is still relatively very new to Asia. A few examples of full-fledged landfill activities initiated in Asia so far are listed below.

\section{Japan}

The first attempt has been performed in Japan where semi-aerobic bioreactor landfill concept so called "Fukuoka Method" .Later on, similar concept has been applied at Ampang Jajar landfill, belong to the Municipal Council of Seberang Parai, Malaysia. The existing disposal had been improved from open dump to bioreactor landfill.

\section{Malaysia}

Ampang Jajar landfill, belong to the Municipal Council of Seberang Parai, Malaysia. Ambitious program was started in 1988 to improve the disposal site with the help of State federal government of Malaysia and Japanese International Corporation Agency (JICA). Within two years the open burning disposal site was turned in to the first sanitary landfill in Malaysia. The improvements target levels are as follows:

Level I: Controlled tipping

Level II: sanitary Landfill with bund and daily cover

Level III: Sanitary Landfill with leachate recirculation

Level IV: Sanitary Landfill with leachate treatment

To understand sustainability in landfills, a good understanding of the stabilization processes, which occur, as well as the fate of the various components that degrade and the nature of the products formed is required. Following steps may be initiated to slowly move from open dumps towards sustainable landfills in Asia

- Fires should be eliminated on the dump site

- Waste tipping should be restricted into small areas and a disposal plan must be followed

- Wastes should be deposited in thin layers of about $50 \mathrm{~cm}$ and compacted appropriately.

- The surface of the newly deposited waste should be covered at the end of the each day with approximately $15 \mathrm{~cm}$ of soil or similar material.

- Install landfill gas collection and rainwater diversion systems.

- Keep the site access roads in good condition to allow vehicles to deposit wastes at designated places as quickly as possible.

- The disposal site should be protected from scavengers/ public by boundary walls and access gates.

- Records of waste deliveries and tipping should be maintained. 
- Carry out Environmental (simple visual inspections to complex chemical analysis) monitoring should be done.

- Provide for essential staff to manage the operation such as a landfill manager, office clerk, security, traffic controller, landfill equipment drivers and mechanic [20].

\section{CONCLUSIONS}

While much of the landfill bioreactor researches have historically occurred in Europe and the US, there is a clear trend of the application of this technology outside of these regions, including Australia, Canada, South America, South Africa, Japan, and New Zealand. Because of the simplicity of implementation, it is expected that landfill bioreactors will have a prominent role in waste management throughout the world, provided the essential elements for proper operation are present [40].

It is now time to seriously consider acceptance and adoption of the bioreactor landfill as a key strategy for deriving short and long-term environmental, regulatory, monetary and societal benefits. The application of landfill bioreactor technology is logical extension of liquid treatment processes. The bioreactor option is a direct result of engineering and building a new generation of environmentally sound landfills; it provides environmental security while permitting and encouraging rapid stabilization of the readily and moderately decomposable organic waste components. Technical challenges remain that must be addressed by the continued funding of large-scale research projects. Results must be reported in a manner that permits universal application of the data. Asia has already being taken the initial step of this modern technique by doing several pilot scale and laboratory scale researches as mentioned in this paper. By keeping aware the people and by implementing new regulations and policies, the way to go for full scale landfill bioreactors are not so far for Asian region. It is hoped that the emerging bioreactor landfill technology will point our solid waste industry towards taking a new look at a very effective option to manage our waste disposal.

\section{ACKNOWLEDGEMENT}

This paper was developed as an activity carried out under Asian Regional Research Program on Environmental Technology (ARRPET) supported by Swedish International Development Cooperation Agency (SIDA).

\section{REFERENCES}

[1] Hughes, K. L., Christy, A. D., Heimlich, J. E., 2007. Bioreactor Landfills. http://ohioline.ogu.edu/index.

[2] Trankler, J., Manandhari, D.R., Xiaoning, Q., Sivapornpun, V., Schöll, W., 2001. Effects of monsooning conditions on the management of landfill leachate in tropical countries, Proceedings Sardinia 2001, Eighth International Waste management and Landfill Symposium, Cagliari, Italy.

[3] Trankler, J., Manandhar, D.R., 2000. Water management of landfills in tropical countries. In: Proceedings of the $12^{\text {th }}$ Congress of the Asia and Pacific Division of the International Association for Hydraulic Engineering and Research, Bangkok.

[4] Pugh, M., 1999. The path to affordable landfill, Waste Management, 58-59. 
[5] Schubeler, P., 1996. Conceptual framework for municilpal solid waste management in low income countries. Urban management program working paper No.9, World Bank.

[6] Hogland, W., Marques, M., Nimmermark, S., 1995. Landfill mining test in Sweden. In proceedings Sardinia $95,5^{\text {th }}$ International Landfill Symposium, Cagliari, Italy.

[7] Cossu, R., Hohland, W., Salerni, E., 1996. Landfill Mining in Europe and USA, ISWA Year book, International Solid Waste Association.

[8] Visvanathan, C., Trankler, J, Basnayake, B.F.A., Chiemchaisri, C., Zhou, G.M., 2003. Landfill management in Asia: Notions about future approaches to appropriate and sustainable solutions. In Sardinia 2003, Proceedings of the 9th International Landfill Symposium, Cagliari, Italy.

[9] Karthikeyan, O.P., Swati, M., Nagendran, R., Joseph K., 2007. Performance of bioreactor landfill with waste mined from a dumpsite, Environ Monit Assess, DOI 10.1007/s100661-007-9709-z.

[10] Shimaoka, T., Lee, N., Matsufuji, Y., Hanashima, M., 1993. Self- purification capacity of the existing solid waste layers in landfills. In Sardinia 1993, Proceedings of the $4^{\text {th }}$ International Land fill Symposium, Cagliari, Italy

[11] Maier, T.B., Steinhauser, E.S., Vasuki, N.C., Pohland, F.G., 1995. Integrated leachate and and landfill gas management. In Sardinia 95, Proceedings of the $5^{\text {th }}$ International Landfill Symposium, Cagliari, Italy.

[12] Van den Broek, B., LAmbropoulos, N.A., Haggett, K., 1995. Bioreactor landfill research in Australia.In Sardinia 95, Proceedings of the $5^{\text {th }}$ International Landfill Symposium, Volume I, Cagliari, Italy.

[13] Yuen, S. T. S., Styles, J. R., McMahon, T. A., 1995. An Active landfill Management by leachate Recirculation: A Review and an Outline of a Full-Scale Project. Proceedings Sardinia 95, 5th International Landfill Symposium, Cagliari, Italy.

[14] Blakey, N.C., Bradshaw, K., Reynolds, P. Knox, K., 1997. Bio-Reactor Landfill-A Field Trial of Accelerated Waste Stabilization. Proceedings from Sardinia 97, Sixth International Landfill Symposium, Volume I, Cagliari, Italy, 13-17 October, 1997.

[15] Ham, R.K., Bookter, T.J., 1982. Decomposition of solid waste in test lysimeter, Journal of Environmental Engineering ASCE, 108, 1147-1170.

[16] Novella, P.H., Ekama, G.A., Blight, G.E., 1997. Effects of liquid replacement statergies on waste stabilization at pilot scale. In Sardinia 97, Proceedings of the $6^{\text {th }}$ International Landfill Symposium, Cagliari, Italy.

[17] Burton, S.A.Q., Watson-Craik, A., 1999. Accelerated landfill refuse decomposition by recirculation of nitrified leachate. In Sardinia 99, Proceedings of the $7^{\text {th }}$ International Landfill Symposium, Volume I, Cagliari, Italy.

[18] Pouech, P., Galtier, L., Labbe, H., Carles, L., Gerbaux, O., 1999. Leachate recirculation control in an extensive bioreactor landfill.In Sardinia 99, Proceedings of the $7^{\text {th }}$ International Landfill Symposium, Cagliari, Italy

[19] Johannessen, L.M., Boyer, G., 1999, Observations of solid waste landfills in developing countries, Urban development division, Waste Management Anchor Team, The World Bank, Washington, USA.

[20] Joseph K., 2002, Solid waste dumpsites to sustainable landfills, Envirovision 2002.

[21] Khire, M.V., Haydar, M.M., 2003. Numerical evaluation of granular blankets for leachate recirculation in MSW landfills. In: Proceedings of the Ninth Sardinia Solid Waste Conference, Cagliary, Italy.

[22] Haydar, M.M., Khire, M.V., 2005. Leachate recirculation using horizontal trenches in bioreactor landfills, Journal of Geotechnical and Geo environmental Engineering ASCE, 131 (7), 837-847. 
[23] Yuen, S.T.S., 2001. Bioreactor Landfills Geoenvironment 2001: 2nd ANZ Conference on Environmental Geotechnics, Newcastle, Australia, 28-30 November 2001. http://webraft.its.unimelb.edu.au/421439/pub/samyuen/references/bioreactor_paper.pdf

[24] Qasim, S.R. Burchinal, J.C. 1970. Leaching from simulated landfills, J. WPCF. 42 (3), 371-379.

[25] Rovers, F.A., Farquhar, G.J., 1973. Infiltration and landfill behavior, Journal of Environmental Engineering ASCE, 5, 671-690.

[26] Pohland, F.G., 1975. Sanitary Landfill Stabilization with Leachate Recycle and Residual Treatment. U.S. Environmental Protection Agency, Cincinnati, Ohio, EPA 600/2-75043.

[27] Pohland, F.G., Gould, J.P., Ghosh, S.B., 1985. Management of hazardous wastes by landfill codisposal with municipal refuse. Journal of Hazardous Waste \& Hazardous Material. 2(2), 143-158.

[28] Onay, T.T., Pohland, F.G., 1998. In situ nitrogen management in controlled bioreactor landfills, Water Research., 32(5), 1383-1392.

[29] Chiemchaisri, C., Chiemchaisri W., Traenkler J., 2007. Minimization and Stabilization of Leachate through Internal Storage and Re-circulation Operation in Tropical Landfill, In: Southeast Asian Water Environment 2, IWA Publishing, U.K.

[30] Petchsri, P., Towprayoon, S., Chaiprasert, P., Nopharatana, A., 2006. The effect of precipitation on municipal solid waste decomposition and methane production in simulated landfill bioreactor with leachate recirculation, Songklanakarin Journal of Science and Technology.29, 615-631.

[31] Swati, M., Kurian, J., Nagendran, R., 2005. Bioreactor landfill lysimeter studies on Indian urban refuse, Proceedings Sardinia 2005, Tenth International Waste Management and Landfill Symposium, Cagliari, Italy.

[32] Jun, D., Yongsheng,Z., Henry, R.K., Mei, H., 2007. Impacts of aeration and active sludge addition on leachate recirculation bioreactor, Journal of Hazardous Materials, 147 (1-2), 240-248.

[33] He, R., Shen, D., Zhu, Y., 2006a. Performance of leachate nitrogen removal in bioreactor landfill system, Chinese journal of applied economy, 17, 520-524.

[34] He, R., Liu, X.-W., Zhang, Z.-J., Shen, D.-S., 2006b. Characteristics of the bioreactor landfill system using an anaerobic-aerobic process for nitrogen removal, Bioresource Technology, 98(13), 2526-2532.

[35] Jianguo, J., Guodong, Y., Zhou, D., Yunfeng, H., Zhonglin, H., Xiangming, F., Shengyong, Z., Chaoping, Z., 2007. Pilot-scale experiment on anaerobic bioreactor landfills in China, Waste Manage., 27(7), 893-901.

[36] Wang, Q., Matsufuji, Y., Dong, L., Huang, Q., Hirano, F., Tanaka, A., 2006.Research on leachate recirculation from different types of landfills, Waste Manage. 26, 815-824.

[37] Luo, F., Chen, W.-Z., Song, F.-Z., Li, X.-P., Zhang, G.-Q., 2004. Comparison between controlled landfill reactor and conditioned landfill bioreactor, J. Environmental Sciences, 16(5), 874-880

[38] Shen, D.-S., He, R., Ren, G.-P., Traore, I., Feng, X.-S., 2002. Effiect of leachate recycling and inoculation on the biochemical characteristics of municipal refuse in landfill bioreactors, J. Environmental Sciences, 14 (3), 406-412.

[39] Mertoglu, B., Calli,B., Inanc,B., Ozturk, I., 2006. Evaluation of in situ ammonia removal in an aerated landfill bioreactor, Process Biochem., 41, 2359-2366.

[40] Reinhart, D.R., McCreanor, P.T., Townsend, T., 2002. The bioreactor landfill: its status and future, Waste Manage. Res. 20, 172-186. 